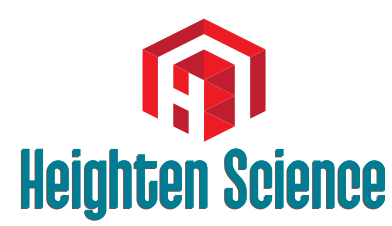

P U B L I C A T I O N S Corporation

\title{
Antiviral activity of Eucalyptus camaldulensis leaves ethanolic extract on herpes viruses infection
}

\author{
Aya Abu-Jafar and Mahmoud Huleihel* \\ Department of Microbiology, Immunology and Genetics, Faculty of Health Sciences, Ben-Gurion \\ University of the Negev,Beer-Sheva, Israel
}

\begin{abstract}
*Address for Correspondence: Mahmoud Huleihel, Department of Microbiology, Immunology and Genetics, Faculty of Health Sciences, Ben-Gurion University of the Negev, Beer-Sheva, Israel, Email: mahmoudh@bgu.ac.il

Submitted: 02 October 2017

Approved: 12 October 2017

Published: 13 October 2017

Copyright: @ 2017 Abu- Jafar A, et al. This is an open access article distributed under the Creative Commons Attribution License which permits unrestricted use, distribution, and reproduction in any medium, provided the original work is properly cited.
\end{abstract}

Keywords: Eucalyptus camaldulensis; Ethanolic extract; HSV; VZV; Acyclovir

\section{Abstract}

Eucalyptus camaldulensis $(\mathrm{Ec})$ is considered as a traditional medicinal plant with valuable therapeutic effects. Here we evaluated the antiviral activity of its ethanolic leave extract on different herpes viruses. Vero cells were infected with either of the tested viruses [herpes simplex virus -1 and 2 (HSV-1, HSV-2) and Varicella-Zoster Virus (VZV)] with or without treatment with Ec extract and viral infection development was evaluated by plaque assay. Our results showed significant antiviral activity of the examined extract against all tested viruses. The $80 \%-\mathrm{MeOH}$ fraction of this extract offered the highest activity against these viruses with $50 \%$ inhibitory concentration $\left(\mathrm{IC}_{50}\right)$ of $0.1 \pm 0.08,0.3 \pm 0.02$ and $1 \pm 0.03 \mu \mathrm{g} / \mathrm{ml}$ against HSV-1, HSV-2 and VZV respectively and $50 \%$ cytotoxicity $\left(\mathrm{CC}_{50}\right)$ at $700 \mu \mathrm{g} / \mathrm{ml}$. The highest antiviral effect of this fraction was obtained mainly when it was added during and post infection (p.i.) or when it was added only p.i. Also, this fraction significantly reduced the amount of infective endogenous viral particles in cells that were treated with the $80 \%-\mathrm{MeOH}$ fraction only post viral entry into the host cells. A synergistic antiviral effect against all tested viruses was also observed when cells were treated with a combination of acyclovir (ACV) and $80 \%-\mathrm{MeOH}$ fraction of Ec. Further study is required for the isolation and identification of the anti-virally active component/s of this fraction.

\section{Introduction}

Viral infections are considered as one of the major causes of death world wide despite the significant progress made in antiviral drug development $[1,3]$. Herpes viruses are DNA $v$ belonging to the family Herpesviridae and are responsible for a variety of mild to severe human diseases, which are sometimes life threatening particularly in immune-comprised patients and neonates [4,5]. After the acute infection, herpes viruses establish latency and persist in different cells of the body, according to the infecting virus, for the life-time. The latent virus is reactivated spontaneously causing recurrent infections in infected patients [6]. Although it can effectively be treated with nucleoside analogs such as acyclovir (ACV), but still the search for new effective antiherpetic drugs is important due to the development of ACV- resistant herpes viruses mutants particularly in immunosuppressed and in immunodeficiency syndrome patients [7-15]. In addition, ACV and other available nucleoside analogs have different undesired side effects (like nausea, vomiting, headache and others) [16] and are not highly effective against reactivated herpes viruses $[17,18]$. Therefore, there is a need for novel effective anti-herpetic drugs with different mode of action from nucleoside derivatives.

Many natural products are known with their antiviral activity and part of them has been already used for the treatment of human viral infections with RNA and DNA viruses $[18,22]$. Different secondary plant metabolites such as flavonoids, saponins, 
lignans, tannins, alkoloids, polyines, thiophenes, phenolic acids and different sugars were found to have significant antiviral activity against variety of viruses [23,25]. Despite the fact that many plant extracts were previously reported for their antiviral activities, their antiviral mechanism of action is still poorly understood.

Eucalyptus camaldulensis (Ec) is an Australian native tree of the genus Eucalyptus and spread in many parts of the world [26]. According to the World Health Organization and different previous studies Eucalyptus leaves and oil have medicinal use for treatment of mild respiratory tract inflammation, bronchitis, asthma, fever and inflammation of the throat $[27,28]$. In addition, eight different components were isolated from Eucalyptus globulus leaves and found to have antiviral activity against Epstein Barr virus [29]. The essential oils of different Eucalyptus species were found to exhibit various biological activities like strong antibacterial activity against different gram $(+)$ and gram $(-)$ bacteria, antifungal, antiviral activities [26,27,30,31], antiinflamatory [28] and antitumor cells activities [32]. The main biologically active components in Eucalyptus essential oil are erpenes and phenylpropanoids [31,33].

Only little information is known about the antiviral activity of Eucalyptus extracts. It was found that crude methanolic extracts of Ec and E. torelliana were active against human enteroviruses: Poliovirus type I, Coxsackievirus B and Echovirus 6 [34]. The main functional components of Ec leaves ethanolic extract were found to include tannins, saponins, cardenolides and flavonoids [34]. In addition, aqueous extract of Eucalyptus fruit had significant activity against HSV-1 while the ethanolic extracts showed little anti-HSV-1 activity [35].

In the present study we investigated the antiviral activity of ethanolic extract of Eucalyptus camaldulensis leaves on various members of the herpes family of viruses (HSV-1, HSV-2 and VZV)

In vitro. Our results showed promising antiviral activity of the examined extract against the tested viruses.

\section{Materials and Methods}

Material. Eucalyptus camaldulensis (Ec) leaves were obtained from trees growing in Israel.

Acyclovir (ACV) was purchased from Sigma Israel.

Preparation of Ec leaves ethanolic extract. Ethanolic extract was prepared from fresh leaves of Ec. The leaves were cut and smashed in $95 \%$ ethanol solution, incubated at $4^{\circ} \mathrm{C}$ with shaking for $48 \mathrm{hs}$, centrifuged at $2000 \mathrm{rpm}$ for $10 \mathrm{~min}$, the supernatant was collected into a clean flask and the pellet was discarded. Then' the collected supernatant was dried by evaporation and dissolved in a 95\% ethanol to give a stock with a concentration of $10 \mathrm{mg} / \mathrm{ml}$. The extracts were diluted with medium containing $2 \%$ newborn calf serum (NBCS) to the appropriate concentrations. Fractionation of ethanolic plant extract. The ethanolic extract was fractionated into different fractions by reverse phase chromatography (RP-C18 Sepack) with a stepwise methanol gradient: $0 \%, 20 \%, 40 \%, 60 \%, 80 \%$ and $100 \%$. Cells and viruses. African green monkey kidney (Vero) cells, which were purchased from the American Type Culture Collection (ATCC), Rockville, MD, USA, were grown in RPMI medium with $10 \%$ new born calf serum and antibiotic mixture (penicillin, streptomycin and nystatin) and incubated at $37^{\circ} \mathrm{C}$ in a humidified air containing $5 \% \mathrm{CO}_{2}$. HSV-1 was obtained from the ATCC (VR-735), HSV2 and VZV were obtained from the virology laboratory Soroka University Medical Center, Beer-Sheva, Israel. 2.5. Cytotoxicity examination. Vero cells were treated with different doses of the extract and the toxicity of the extract was evaluated by: (a) Daily morphological changes observation by optical inverted microscope. (b) MTT assay which was performed as previously described [36]. Briefly, the appropriate cell 
cultures were incubated with $50 \mu \mathrm{g} / \mathrm{ml}$ MTT solution at $37^{\circ} \mathrm{C}$ for $5 \mathrm{~h}$. This solution was converted by mitochondrial succinate dehydrogenase enzyme into insoluble formazan (purple). Then the cultures were washed with saline and SDS solution was added to dissolve the formazan. The absorbance was measured at $570 \mathrm{~nm}$ after overnight incubation at $37^{\circ} \mathrm{C}$, indicating the metabolic activity of the cells.

Viral infection. The cells were plated at $2 \times 10^{5}$ cells/well in 24-well culture plates, in RPMI with $10 \%$ NBCS and antibiotics. After overnight incubation the medium was removed and the cells were infected with $1 \mathrm{PFU} /$ cell for two hours at $37^{\circ} \mathrm{C}$. The infection development was evaluated by plaque assay as previously described [37]. Briefly, the unabsorbed virus was removed after $2 \mathrm{~h}$ infection and cells were overlaid with either a layer of $0.6 \%$ carboxymethylcelleluse (CMC). Two days post-infection (p.i.) the CMC overlay was removed, cell monolayers were fixed with $10 \%$ formalin in saline, stained with crystal violet and plaques were counted.

Antiviral mechanism of action of the examined product. The infected cells were treated with increasing concentrations of the product at different times before, during or after infection as follow: (1) only before infection- the cell monolayers were incubated with medium containing the fraction for $2 \mathrm{~h}$., then the medium was removed and the cells were infected with 1 moi of the appropriate virus without further treatment with the fraction; (2) only during infection time and then the cell cultures medium replaced with medium without the examined product; (3) only p.i.- cells were treated with the tested product immediately after $2 \mathrm{~h}$ infection with the virus. The treatment was continued up to the end of the experiment; (4) during and p.i- cells were treated with the product at the time of infection and the treatment continued up to the end of the experiment.

To study possible direct effect of the tested product on virus particles infectivity, $10^{4}$ PFU (plaque forming unit) of the appropriate virus particles were pre-incubated with $10 \mu \mathrm{g} / \mathrm{ml}$ of the tested product at $22^{\circ} \mathrm{C}$ for $30 \mathrm{~min}$. Then these mixtures were diluted $10^{4}$ fold with fresh medium (to minimize the concentration of the antiviral agent at the time of infection) and cell monolayers were infected with the diluted mixture.

In order to examine possible effect of the tested product on intracellular- HSV-1 replication, cells were infected for $2 \mathrm{~h}$ by HSV-1 without treatment with the tested product. Then, the medium was removed and replaced with fresh medium with or without the tested extract and the infected cells were removed from the wells by treatment with trypsin at $20 \mathrm{hrs}$. p.i. The obtained cells were pelleted by centrifugation at $1500 \mathrm{rpm}$ for 5 minutes, washed three times with saline solution. Each pellet was resuspended with $100 \mu \mathrm{l}$ of physiological saline solution and the cells were broken by freezing and thawing them. Cell debris were removed by centrifugation at 1500 rpm for 5 minutes and the mixture containing the endogenous virus was then used for infecting cell monolayers.

Cooperative activity. Synergistic or additive activity between the tested Ec fraction and acyclovir (ACV) was examined by treating the cells with different combinations of the fraction and ACV at the time and post-infection with the virus.

\section{Results and Discussion}

Cytotoxicity of extract. Vero cell monolayers were treated with various doses of Ec leaves ethanolic extract for 3 days and the cytoxicity of the extract was evaluated by daily morphological observations and by MTT assay as described in "Materials and Methods" section. The concentration found to cause $50 \%$ toxicity $\left(\mathrm{CC}_{50}\right)$ of this extract was $200 \mu \mathrm{g} / \mathrm{ml}$ (data not shown).

Antiviral activity of Ec extract against herpes viruses. In order to examine possible antiviral activity of Ec extract on various herpes viruses' infection, vero cell monolayers 
were treated with different doses of the extract at the time of infection with 1 m.o.i. of HSV-1, HSV-2 or VZV. The treatment was continued up to the end of the experiment and the antiviral activity was evaluated by plaque assay. The obtained results showed a significant inhibition of all tested viruses infection as can be seen in figure 1 . The concentrations of the extract that caused a $50 \%$ plaque inhibition (IC50) of HSV-1, HSV2 and VZV infection were 1,3,0.1 $\mu \mathrm{g} / \mathrm{ml}$ respectively (Figure 1). These results are in agreement with different previous studies which showed significant antiviral activity of etanolic plant extracts against herpes viruses infections[21,38,39]. However, some other previous studies, in contrast to our results, had reported differential antiviral activity of plant extracts on these viruses [40-43], probably due to their different biochemical and serological properties $[44,45]$.

The selectivity index (SI) (determined as $\mathrm{CC}_{50} / \mathrm{IC}_{50}$ ) of Ec extract against VZV was the highest and the most impressive compared to HSV-1 and HSV-2 as can be seen in figure 2. Also, it can be seen that the SI of this extract against VZV was markedly higher than that of HSV-1 and HSV-2. Although the SI values of this extract against the tested viruses were lower than that the positive control ACV (Figure 2), it still worthwhile to continue examining their antiviral potential against these viruses because after isolating and purifying the anti-virally active component of this extract it will most likely improve its antiviral potential.

Ec extract's fractions antiviral activity. Ec extract was separated into different fractions with a methanol gradient as detailed in "Materials and Methods" section and tested for antiviral activity. Our results showed that the highest antiviral activity

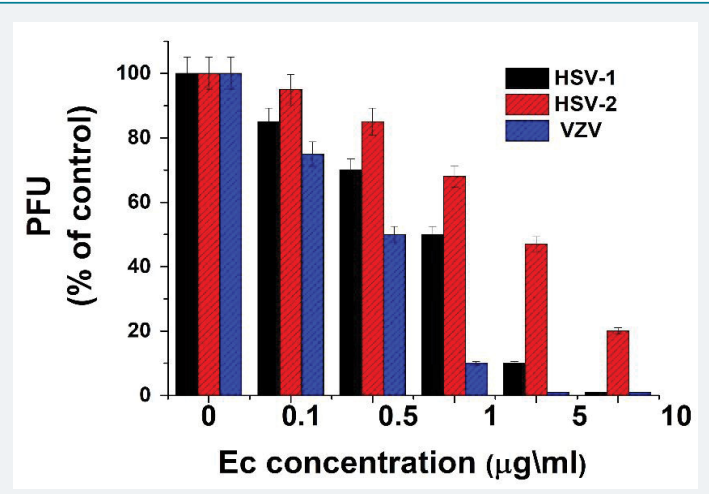

Figure 1: Antiviral activity of Ec leaf ethanolic extract on herpes viruses. Vero cells were infected with $1 \mathrm{~m}$. o.i. of different herpes viruses with or without treatment with various concentrations of $E c$ extract. The cells were treated with the extract at the time of infection and post infection (p.i.) up to the end of the experiment. Plaque numbers (PFU) are presented as a percentage of the positive control (infected but untreated cell cultures). Values are means $\pm S D(n=3)$.

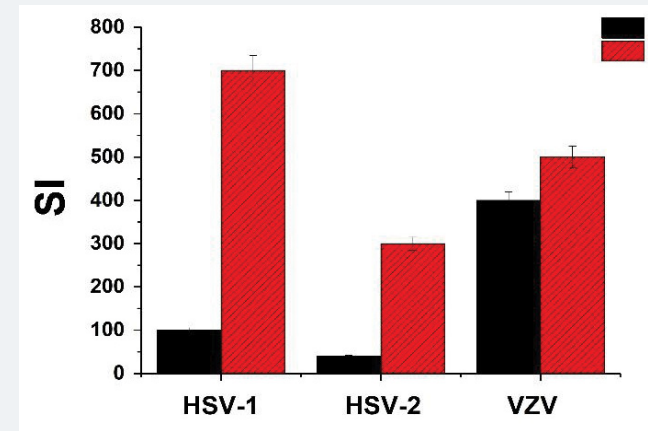

Figure 2: Selectivity index (SI) of Ec leaf ethanolic extract and acyclovir (ACV) against HSV-1, HSV-2 and VZV. SI was determined as CC50 /IC50. Values are means $\pm S D(n=3)$. 
against all tested viruses was obtained with the $80 \%-\mathrm{MeOH}$ fraction while the other fractions did not show any significant activity (Table 1). As expected the $80 \%-\mathrm{MeOH}$ fraction had significantly higher SI compared to the crude extract and also interestingly higher than the SI of ACV (Table 1). This result is reasonable due to the isolation and purification of the anti-virally active component. These results are in contrast to our previous findings which showed that $80 \% \mathrm{MeOH}$ fraction of $\mathrm{F}$. binjamina and $\mathrm{L}$. candidum leaves ethanolic extracts was active only against HSV-1 and HSV-2 while the $60 \% \mathrm{MeOH}$ fraction was highly active against VZV infection [21].

Effect of the Ec 80\%-MeOH fraction on various steps of the viral infection. Trying to examine which step of the viral infection is blocked by Ec $80 \%-\mathrm{MeOH}$ fraction; cells were infected with 1 m.o.i. of the tested herpes viruses and treated with $5 \mu \mathrm{g} / \mathrm{ml}$ of this fraction at different time before, at or after infection as detailed in "Materials and Methods" section. As can be seen from the results presented in figure 3 the highest and most effective inhibition of all tested viruses infection was obtained when the treatment with the product was at the time and after infection (about 100\% inhibition). These results are in agreement with previous studies reported that the anti-virally active natural products mainly prevent early steps of the viral infection such as direct effect on the viral particles, virus adsorption and/or penetration into the host cells $[5,14,38,40,46]$. When the cells were treated only at the time of infection or only p.i. there was also a significant inhibition (over 50\%) of the viral infection development

\begin{tabular}{|c|c|c|c|c|c|c|c|}
\hline \multirow[b]{2}{*}{ Ec Fractions } & \multirow[b]{2}{*}{$\mathrm{CC}_{50}(\mu \mathrm{g} / \mathrm{ml})$} & \multicolumn{2}{|c|}{ HSV-1 } & \multicolumn{2}{|c|}{ HSV-2 } & \multicolumn{2}{|c|}{ VZV } \\
\hline & & $\begin{array}{c}\mathrm{IC}_{50} \\
(\mu \mathrm{g} / \mathrm{ml})\end{array}$ & SI & $\begin{array}{c}I_{50} \\
(\mu \mathrm{g} / \mathrm{ml})\end{array}$ & SI & $\begin{array}{c}\mathrm{IC}_{50} \\
(\mu \mathrm{g} / \mathrm{ml})\end{array}$ & SI \\
\hline Ethanolic extract & $200 \pm 8$ & $2 \pm 0.4$ & 100 & $5 \pm 0.05$ & 40 & $0.5 \pm 0.04$ & 400 \\
\hline $0 \%-\mathrm{MeOH}$ & $500 \pm 65$ & Inactive & - & Inactive & - & Inactive & - \\
\hline $20 \%-\mathrm{MeOH}$ & $600 \pm 40$ & $200 \pm 14.5$ & 3 & $280 \pm 8.0$ & 2.1 & $170 \pm 5.1$ & 3.5 \\
\hline $40 \%-\mathrm{MeOH}$ & $600 \pm 36$ & $150 \pm 5.5$ & 4 & $120 \pm 6.6$ & 5 & $190 \pm 7.3$ & 3.1 \\
\hline $60 \%-\mathrm{MeOH}$ & $550 \pm 16$ & $100 \pm 4.0$ & 5.5 & $110 \pm 4.5$ & 5 & $90 \pm 1.8$ & 6.1 \\
\hline $80 \%-\mathrm{MeOH}$ & $500 \pm 45$ & $0.5 \pm 0.03$ & 1000 & $1.5 \pm 0.03$ & 333 & $0.4 \pm 0.01$ & 1250 \\
\hline $100 \%-\mathrm{MeOH}$ & $400 \pm 32$ & $250 \pm 13.1$ & 1.6 & $150 \pm 13.7$ & 2.6 & $185 \pm 3.9$ & 2.1 \\
\hline ACV & $70 \pm 4$ & $0.1 \pm 0.005$ & 700 & $0.25 \pm 0.01$ & 280 & $0.15 \pm 0.007$ & $466.7 \pm 25$ \\
\hline
\end{tabular}

Vero cell monolayers were treated with different doses of Ec purified fractions at the time and p.i. The $\mathrm{CC}_{50}$ and the IC values of these fractions were determined by MTT and plaque assay as detailed in "Material and Methods" section. Values are means $\pm S D(n=3)$.

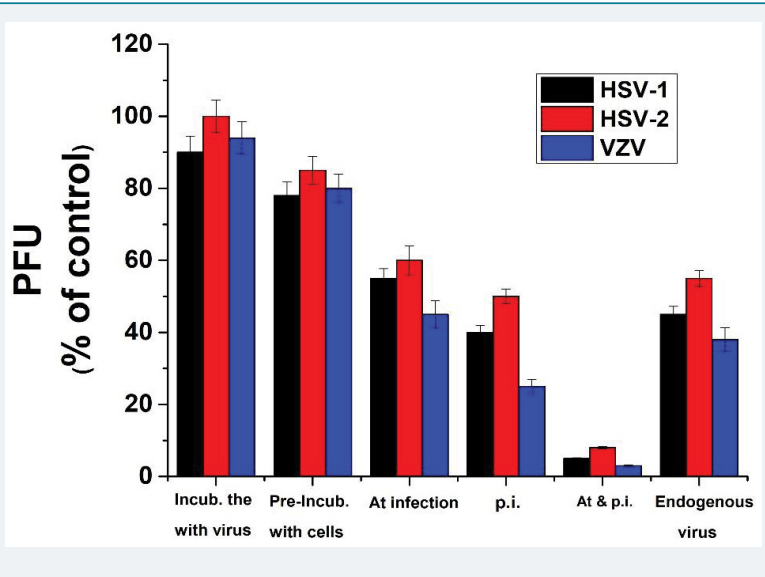

Figure 3: Effect of the treatment time with $\mathrm{Ec} 80 \%-\mathrm{MeOH}$ fraction on herpes viruses' infection. Vero cells were infected with $1 \mathrm{~m}$.o.i. of the herpes viruses and treated with $5 \mu \mathrm{g} / \mathrm{ml}$ of Ec $80 \%-\mathrm{MeOH}$ fraction for different periods of time as follow: only for $2 \mathrm{~h}$ before infection, only during infection, only p.i. or during and p.i. up to the end of the experiment. Furthermore, $10^{4} \mathrm{PFU}$ of the appropriate virus particles were pre-incubated with $10 \mu \mathrm{g} / \mathrm{ml}$ of Ec $80 \%$ $\mathrm{MeOH}$ fraction at $22^{\circ} \mathrm{C}$ for $30 \mathrm{~min}$. Then these mixtures were diluted $10^{4}$ fold with fresh medium and cell monolayers were infected with the diluted mixture. PFU of the treated cultures are presented as a percentage of the positive control. Values are means $\pm S D(n=3)$. 
however, when treated only before the infection, there was only a small reduction (about 15\%) in the viral infection (Figure 3). This result may indicate that there is no significant interaction between the examined product and the host cells receptors or probably this interaction is a weak and reversible and therefore, the product was easily washed and removed from the cells before infection. This result is supported also by previous studies which did not find any significant interaction between plant alcoholic extracts and cell receptors $[22,39,42]$. In addition, when the viral particles were preincubated with the examined extract fraction there was no significant inhibition of the viral infection (Figure 3), which means that hat there was no direct interaction between the tested extract fraction and either of the tested viruses. These results are in contrast with previous studies $[21,42,47]$ which showed strong direct interaction between the ethanlic extracts of different plants and HSV-1 or HSV-2 particles, while our previous study showed that there was no notable interaction with VZV in the case of Passiflora extract [48].

As mentioned above, treatment of the infected cells only p. i. caused significant partial inhibition of the viral infection with the different examined viruses (Figure 3 ). This inhibition may be a result of interfering with internal steps during the viral replication cycle after the penetration of the virus into the host cells or probably a result of reinfection inhibition. In order to examine these possibilities, cells were infected with either of the tested viruses and treated with $10 \mu \mathrm{g} / \mathrm{ml}$ of the extract fraction after $2 \mathrm{~h}$ of infection. At 20 hours p.i. the internal virus infectivity was examined as detailed in"Materials and Methods" section. Our results (Figure 3) showed that all treated cell monolayers with Ec fraction showed over 50\% inhibition of the different tested viruses' infection development (Figure 3). It seems that this fraction caused a significant inhibition in the production of infective viral particles production inside the host cells. It is well established that the $80 \%-\mathrm{MeOH}$ fraction of various plant leaves is rich with flavonoids such as quercetin, quercetin 3-rhamnoside and quercetin 7-rhamnoside which are known to have antiviral activities [21,49,50].

Cooperative activity of Ec $80 \%-\mathrm{MeOH}$ fraction with the commercial anti-herpetic drug ACV. In order to examine possible cooperative activity between ACV and Ec 80\%$\mathrm{MeOH}$ fraction, vero cells were infected and treated with various combinations of ACV and Fc fraction consisting of various doses of either product (focusing in lower concentrations which are not significantly active against herpes viruses' infection). Our results showed a significant cooperative antiviral activity between ACV and Ec fraction (Figure 4). When the cells were treated separately with $0.1 \mu \mathrm{g} / \mathrm{ml}$ of Ec fraction or

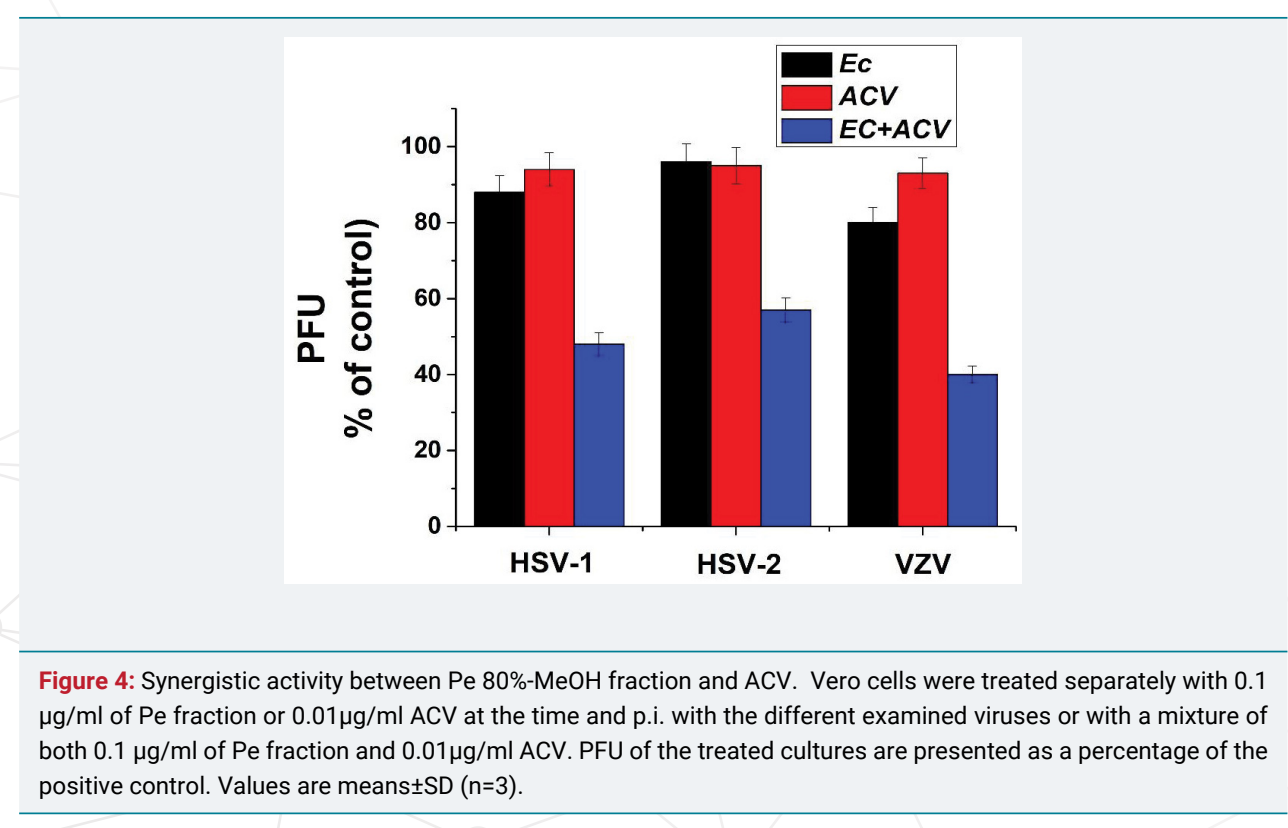


$0.01 \mu \mathrm{g} / \mathrm{ml} \mathrm{ACV}$ at the time of infection and p.i., a low antiviral activity (10-20\%) was obtained. However, when the cells were treated with a mixture of both $0.1 \mu \mathrm{g} / \mathrm{ml}$ of Ec fraction and $0.01 \mu \mathrm{g} / \mathrm{ml} \mathrm{ACV}$, a significant inhibition ( $75 \%)$ of the viral infection was observed. This cooperative activity which probably is a synergistic activity between the examined Ec fraction and ACV is very important and can be beneficial for future use contributing to a significant reduction in both the side effects and costs of ACV.

\section{Conclusions}

1. Ec ethanolic extract showed strong antiviral activity against different members of the herpes viruses' family (HSV-1, HSV-2 and VZV).

2. The $80 \%-\mathrm{MeOH}$ fraction of Ec was the most anti-virally effective against all tested viruses with SI significantly higher that of the crude extract and even higher than that of ACV.

3. It seems that the $80 \%-\mathrm{MeOH}$ fraction of Ec interferes with different stages of the viral infection such as inhibiting early stages of the infection (viral adsorption/ penetration into the host cells) and probably blocking one or more steps during the virus replication inside the host cells after their penetration. This effect on the different stages of the viral infection can be done by different components of this EC fraction.

4. A strong cooperative antiviral activity was found between the $80 \%-\mathrm{MeOH}$ fraction of Ec and ACV.

5. Further study is required for the isolation and purification of the anti-virally active components of the $80 \%-\mathrm{MeOH}$ fraction of Ec.

\section{References}

1. Müller V, Chávez JH, Reginatto $F H$, Zucolotto $S M$, Niero R, et al. Evaluation of antiviral activity of South American plant extracts against herpes simplex virus type 1 and rabies virus. Phytother Res. 2007; 10: 970-974. Ref: https://goo.gl/Y5BY1V

2. Elion GB, Furman PA, Fyfe JA, de Miranda P, Beauchamp L, et al. Selectivity of action of an antiherpetic agent, 9-(2-hydroxyethoxymethyl)guanine. Proc Natl Acad Sci U S A. 1977; 12: 57165720. Ref: https://goo.gl/hFkJCr

3. Meyers JD, Wade JC, Mitchell CD, Saral R, Lietman PS, et al. Multicenter collaborative trial of intravenous acyclovir for treatment of mucocutaneous herpes simplex virus infection in the immunocompromised host. Am J Med. 1982; 73: 229-235. Ref: https://goo.gl/meF9HM

4. Snoeck R. Antiviral therapy of herpes simplex. Int J Antimicrob Agents. 2000; 16: 157-159. Ref: https://goo.gl/jhNJgQ

5. Khan MT, Atherb A, Thompson KD, Gambari R. Extracts and molecules from medicinal plants against herpes simplex viruses. Antiviral Res. 2005; 67: 107-119. Ref: https://goo.gl/37YbHC

6. Whitley RJ, Bernard Roizman. Herpes simplex virus infections. Lancet. 2001; 357: 1513-1518. Ref: https://goo.gl/eXTLqC

7. Celum C1, Wald A, Hughes J, Sanchez J, Reid S, et al. Effect of aciclovir on HIV-1 acquisition in herpes simplex virus 2 seropositive women and men who have sex with men: a randomised, doubleblind, placebo-controlled trial. Lancet. 2008; 371: 2109-2119. Ref: https://goo.gl/jeCvWE

8. De Clercq E. Antiviral drugs in current clinical use. J Clin Virol. 2004; 30: 115-133. Ref: https://goo.gl/TCxt1x

9. Bao B1, Meng Z, Li N, Meng Z, Zhang L, et al. Design Synthesis and Antiviral Activity Studies of Schizonepetin Derivatives. Int J Mol Sci. 2013; 14: 17193-17203. Ref: https://goo.gl/PMF8sy

10. Fiddian AP, Brigden D, Yeo JM, Hickmott EA. Acyclovir: An update of the clinical applications of this antiherpes agent. Antiviral Res. 1984; 4: 99-117. Ref: https://goo.gl/utMMLp

11. Erlich KS, Mills J, Chatis P, Mertz GJ, Busch DF, et al. Acyclovir-Resistant Herpes Simplex Virus Infections in Patients with the Acquired Immunodeficiency Syndrome. N Engl J Med. 1989; 320: 293296. Ref: https://goo.gl/c7ECYP 
12. Oliver NM, Collins P, Van der Meer J, Van't Wout JW. Biological and biochemical characterization of clinical isolates of herpes simplex virus type 2 resistant to acyclovir. Antimicrob Agents Chemother. 1989; 33: 635-640. Ref: https://goo.gl/8XuHqe

13. Burrelab S, Aimeb C, Hermetb L, Ait-Arkoub Z, Aguta H, et al. Surveillance of herpes simplex virus resistance to antivirals: A 4-year survey. Antiviral Res. 2013; 100: 365-372. Ref: https://goo.gl/nVgrTt

14. Churqui MP, Lind L, Thörn K, Svensson A, Savolainen O, et al. Extracts of Equisetum giganteum $L$ and Copaifera reticulate Ducke show strong antiviral activity against the sexually transmitted pathogen herpes simplex virus type 2. J Ethnopharmacol. 2017; 210: 192-197. Ref: https://goo.gl/Xb2H66

15. Frobert E, Burrel S, Ducastelle-Lepretre S, Billaud G, Ader F, et al. Resistance of herpes simplex viruses to acyclovir: An update from a ten-year survey in France. Antiviral Res. 2014; 111: 36-41. Ref: https://goo.gl/Az5DkS

16. Field AK, Biron KK. "The end of innocence" revisited: resistance of herpesviruses to antiviral drugs. Clin Microbiol Rev. 1994; 7: 1-13. Ref: https://goo.gl/VD1Hy2

17. İlker Devrim, Hasan Tezer, Göknur Haliloğlu, Ateş Kara, Gülten Seçmeer. Relapsing Herpes simplex virus encephalitis despite high-dose acyclovir therapy: a case report. Turk J Pediatr. 2008; 50: 380382. Ref: https://goo.gl/Q429CT

18. Picton SF, Flatt PR, McClenaghan NH. Differential Acute and Long Term Actions of Succinic Acid Monomethyl Ester Exposure on Insulin-Secreting BRIN-BD11 Cells. Int J Exp Diabetes Res. 2001; 2: 19-27. Ref: https://goo.gl/vFehUS

19. Clark A . Natural products as a resource for new drugs. Pharm Res. 1996; 13: 1133-1141. Ref: https://goo.gl/4tiws9

20. Bailly C1, Perrine D, Lancelot JC, Saturnino C, Robba M, et al. Sequence-selective binding to DNA of bis(amidinophenoxy)alkanes related to propamidine and pentamidine. Biochem J. 1997; 323: 23-31. Ref: https://goo.gl/zuuDNz

21. Yarmolinsky L, Zaccai M, Ben-Shabat S, Mills D, Huleihel M. Antiviral activity of ethanol extracts of Ficus binjamina and Lilium candidum in vitro. N Biotechnol. 2009; 26: 307-313. Ref: https://goo.gl/cJA2zf

22. Yarmolinsky L, Huleihel M, Zaccai M, Ben-Shabat S. Potent antiviral flavone glycosides from Ficus benjamina leaves. Fitoterapia. 2012; 83: 362-367. Ref: https://goo.gl/zecCdJ

23. Chiang LC, Cheng HY, Liu MC, Chiang W, Lin CC. In Vitro anti-herpes simplex viruses and antiadenoviruses activity of twelve traditionally used medicinal plants in Taiwan. Biol Pharm Bull. 2003; 26: 1600-1604. Ref: https://goo.gl/aZGTbE

24. Jassim SA, Naji MA. Novel antiviral agents: a medicinal plant perspective. J Appl Microbiol. 2003; 95: 412-427. Ref: https://goo.gl/3gLiUo

25. Sanchez Palomino S, Abad MJ, Bedoya LM, García J, Gonzales E, et al. Screening of South American Plants against Human Immunodeficiency Virus: Preliminary Fractionation of Aqueous Extract from Baccharis trinervis. Biol Pharm Bull. 2002; 25: 1147-1150. Ref: https://goo.gl/QXee6r

26. Elaissi A, Rouis Z, Salem NA, Mabrouk S, ben Salem Y, et al. Chemical composition of 8 eucalyptus species' essential oils and the evaluation of their antibacterial, antifungal and antiviral activities. BMC Complement Altern Med. 2012; 12: 81-81. Ref: https://goo.gl/7bTF4H

27. Gemechu A, Giday M, Worku A, Ameni G. In vitro Anti-mycobacterial activity of selected medicinal plants against Mycobacterium tuberculosis and Mycobacterium bovis Strains. BMC Complement Altern Med. 2013; 13: 291-291. Ref: https://goo.gl/kcmWeU

28. Almeida IF, Fernandes E, Lima JL, Valentão P, Andrade PB, et al. Oxygen and Nitrogen Reactive Species Are Effectively Scavenged by Eucalyptus globulus Leaf Water Extract. J Med Food. 2009; 12 : 175-183. Ref: https://goo.gl/S8AWVa

29. Takasaki M, Konoshima T, Fujitani K, Yoshida S, Nishimura H, et al. Inhibitors of skin-tumor promotion. VIII. Inhibitory effects of euglobals and their related compounds on Epstein-Barr virus activation. (1). Chem Pharm Bull (Tokyo). 1990; 38: 2737-2739. Ref: https://goo.gl/xeVpFM

30. Brochot A, Guilbot A, Haddioui L, Roques C. Antibacterial, antifungal, and antiviral effects of three essential oil blends. Microbiologyopen. 2017; 6: e00459. Ref: https://goo.gl/SxkZDH

31. Dhifi W, Bellili S, Jazi S, Bahloul N, Mnif W. Essential Oils' Chemical Characterization and Investigation of Some Biological Activities: A Critical Review. Medicines (Basel). 2016; 3: 25. Ref: https://goo.gl/7WX1ck 
32. Döll-Boscardin PM, Sartoratto A, Sales Maia BH, Padilha de Paula J, Nakashima T, et al. In Vitro Cytotoxic Potential of Essential Oils of Eucalyptus benthamii and Its Related Terpenes on Tumor Cell Lines. Evid Based Complement Altern Med. 2012; 2012: 342652. Ref: https://goo.gl/FpGa7E

33. Astani A, Reichling J, Schnitzler P. Comparative Study on the Antiviral Activity of Selected Monoterpenes Derived from Essential Oils. Phytother Res. 2010; 24: 673-679. Ref: https://goo.gl/2MQqoB

34. Adeniyi BA, OO Ayepola, FD Adu. The antiviral activity of leaves of Eucalyptus camaldulensis (Dehn) and Eucalyptus torelliana (R. Muell). Pak J Pharm Sci. 2015; 28: 1773-1776. Ref: https://goo.gl/haPqTW

35. Ju HQ, Wang SY, Pei Y, Xiang YF, Li S, et al. [In vitro study on the anti-HSV-1 and HBV activities of extracts from the fruit of Eucalyptus maidenii]. Zhong Yao Cai. 2011; 34: 242-245. Ref: https://goo.gl/6XJw8E

36. YufangShi, Barbara S.Kornovski, RashminSavani, Eva ATurley. A rapid. multiwell colorimetric assay for chemotaxis. J Immunol Methods. 1993; 164: 149-154. Ref: https://goo.gl/FJss6e

37. Mahmoud Huleihel, Vladimir Ishanu, Jacov Tal, Shoshana (Malis) Arad. Antiviral effect of red microalgal polysaccharides on Herpes Simplex and Varicella zoster viruses. J Appl Phycology. 2001; 13: 127-134. Ref: https://goo.gl/MksrhV

38. Kirsten Geschera, Joachim Kühnb, Wali Hafezi, bAndreas Louisa, Andrea Derksen, et al. Inhibition of viral adsorption and penetration by an aqueous extract from Rhododendron ferrugineum $L$. as antiviral principle against herpes simplex virus type-1. Fitoterapia. 2011; 82: 408-413. Ref: https://goo.gl/u4riYt

39. Noam R, M Huleihel, Michele Zaccai. Stress conditions during plant growth increase the anti-herpetic properties of Lilium candidum leaf extracts and fractions. J Med Plants Res. 2015; 9: 954-961. Ref: https://goo.gl/4whu4n

40. Cheng HY, Lin LT, Huang HH, Yang CM, Lin CC. Yin Chen HaoTang, a Chinese prescription, inhibits both herpes simplex virus type-1 and type-2 infections in vitro. Antiviral Res. 2008; 77: 14-19. Ref: https://goo.gl/kPZ5Wq

41. Arena A, Bisignano G, Pavone B, Tomaino A, Bonina FP, et al. Antiviral and immunomodulatory effect of a lyophilized extract of Capparis spinosa L. buds. Phytother Res. 2008; 22: 313-317. Ref: https://goo.gl/qv7bUX

42. Cheng HY, Yang CM, Lin TC, Lin LT, Chiang LC, et al. Excoecarianin, Isolated from Phyllanthus urinaria Linnea, Inhibits Herpes Simplex Virus Type 2 Infection through Inactivation of Viral Particles. Evid Based Complement Alternat Med. 2011; 2011: 259103. Ref: https://goo.gl/LXreMR

43. Yang CM, Cheng HY, Lin TC, Chiang LC, Lin CC. Acetone, ethanol and methanol extracts of Phyllanthus urinaria inhibit HSV-2 infection in vitro. Antiviral Res. 2005; 67: 24-30. Ref: https://goo.gl/ixSvJK

44. Wyrwicz LS, Rychlewski L. Identification of Herpes TATT-binding protein. Antiviral Res. 2007; 75 167-172. Ref: https://goo.gl/4Qi1kA

45. Field HJ, S Biswas, IT Mohammad. Herpesvirus latency and therapy-from a veterinary perspective. Antiviral Res. 2006; 71: 127-33. Ref: https://goo.gl/U3kGGg

46. Kesharwani A, Polachira SK, Nair R, Agarwal A, Mishra NN, et al. Anti-HSV-2 activity of Terminalia chebula Retz extract and its constituents, chebulagic and chebulinic acids. BMC Complement Altern Med. 2017; 17: 110. Ref: https://goo.gl/UTsnZZ

47. Gescher K, Kühn J, Lorentzen E, Hafezi W, Derksen A, et al. Proanthocyanidin-enriched extract from Myrothamnus flabellifolia Welw. exerts antiviral activity against herpes simplex virus type 1 by inhibition of viral adsorption and penetration. $J$ Ethnopharmacol. 2011; 134: 468-474. Ref: https://goo.gl/Fe1Yc3

48. Jabareen A, M Huleihil, M Huleihel. Effect of Extracts of Passiflora edulis Leaves on Herpes Viruses Infection. J Virol Antivir Res. 2013; 2: 1-6. Ref: https://goo.gl/JcX4jG

49. Choi HJ, Song JH, Park KS, Kwon DH. Inhibitory effects of quercetin 3-rhamnoside on influenza A virus replication. Eur J Pharm Sci. 2009; 37: 329-333. Ref: https://goo.gl/1BrUuS

50. Mucsi I, Prágai BM. Inhibition of virus multiplication and alteration of cyclic AMP level in cell cultures by flavonoids. Experientia. 1985; 41: 930-931. Ref: https://goo.gl/GGqxUA 